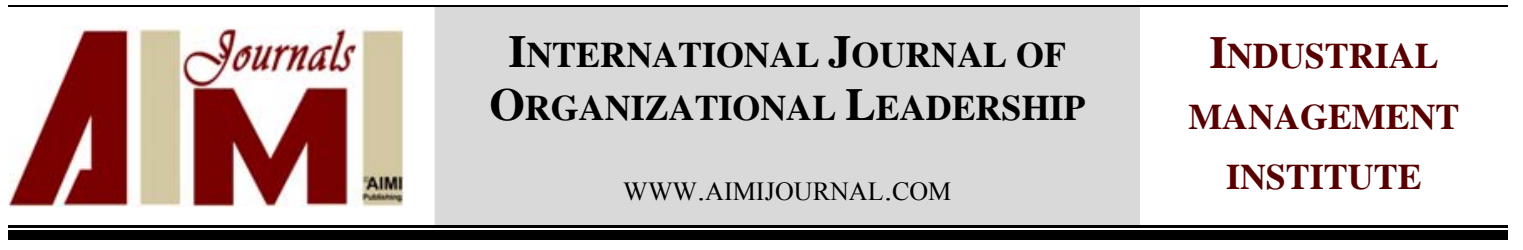

\title{
Developing a communication model between banking services quality via mediating variables of quality of relationship with customers and satisfaction with customer loyalty: A case study of Tejarat Bank
}

\author{
Hossein Rahimi Koloor \\ Associate Professor, University of Mohaghegh Ardabili, Ardabil, Iran
}

\begin{tabular}{|c|c|}
\hline & ABSTRACT \\
\hline $\begin{array}{l}\text { Keywords: } \\
\text { Loyalty, Customer } \\
\text { Orientation, Customer } \\
\text { Satisfaction, Structural } \\
\text { Equation Modeling (SEM), } \\
\text { Tejarat Bank }\end{array}$ & $\begin{array}{l}\text { This study develops a communication model. The purpose of this research was designing a } \\
\text { regression model and developing a structural equation modeling (SEM) for earning loyalty of } \\
\text { Tejarat Bank customers. Given this concept, a questionnaire was designed and distributed } \\
\text { among branches of Tejarat Bank in Ardabil. The data analyzed using LISREL software } \\
\text { within the framework of path analysis using SEM model. Research results suggested that the } \\
\text { quality of banking services, customer satisfaction, and the quality of bank relationship with } \\
\text { customers had the most effects on customer loyalty, respectively. The findings of the study }\end{array}$ \\
\hline $\begin{array}{l}\text { Correspondence: } \\
\text { h clever@uma ac }\end{array}$ & are discussed in detail. \\
\hline
\end{tabular}

CAIMI Journals

\section{Introduction}

Banking system is considered as one of the most effective elements in economic development of each country. It tries to play a crucial role in development and diversification of its financial services. Banking system does this through continually engaging in an endless struggle to derive substantial benefit and to accomplish their future goals through honoring the customers and giving assurance to increase the level of customer satisfaction, promoting 
the quality of banking services, and through developing the level of its relationship with customers. In order to achieve this goal, attracting and keeping customers and guaranteeing their loyalty remain important drivers in banking. In today's competitive world, customers are considered to be the core and main structures of marketing activities. Following this, the level of customer satisfaction is in the service producers' and service presenters' center of attention. Success and survival of each industry and providing high level services for customers depend on evaluation of customers' demands and their expectations. Hence, their consequences would result in loyalty increment, attracting new customers, and increasing profitability (Kaur, Sharma, \& Kapoor, 2012).

With expansion of marketing and competition concepts, monetary and financial organizations and institutions have perceived that earning strategic goals are based on customer orientation, especially in competitive marketing situations with limited number of customers. Put simply, key factors in success of businesses are attracting and keeping customers and customer orientation (Tahvildari, 2008).

Today, organizations act based on customers because customers tend to be real rulers of markets in economic age. Therefore, organizations should learn how to move from concentration on products or services to concentration on customer. They should respect them as an asset that needs management and boosting to the highest level of performance. Iranian banking industry, as one of the most influential elements in country's economy (Rahmani \& Varedi, 2013) has recognized that customers are their most important asset and they consider the relationship with customers as beneficial reactions. The continuance of this procedure necessitates a proper management (Salarzehi \& Amiri, 2012).

In today's competitive and challenging environment, a ground should be provided for economic businesses such as banks in which they can harmonize themselves with needs of society and cope with customers' environmental and social needs; in this case, we can observe movement toward customer orientation. Based on this idea, keeping existing customers and then turning them into regular customers are basic parts of marketing. Nowadays, just having relationship with customers to have loyal customers is not enough. The quality of this relationship is also of great importance. The quality of relationship depends on customer perception and his evaluation of reaction with staff and their behavior in encountering with customers (Rahimnia, Harandi, \& Fatemi, 2013).

The existing studies clearly indicate that efficient management and strong relationship with customers lead to deep satisfaction and loyalty of customers. Moreover, the behavior of 
employees who are in the first line of interaction with customers along with the effects of human dimensions, the technological effects, and physical and tangible effects of service qualities had a profound effect on customer satisfaction, customer loyalty, and their attraction (Lenka, Suar, \& Mohapatra, 2009). Modern banking services and new technologies (Singah $\&$ Rahul, 2010), customer satisfaction along with customer perception of services quality (Gustafsson, Johnson, \& Roos, 2005), and also building good and effective relationships with customers through relationship marketing between bank and customer (Rahmani \& Varedi, 2013) all had substantial effects on customer loyalty. Regarding the theoretical frameworks presented by Kotler and Armstrong (2012), Helgessen and Nesset (2007), and Spreng and Mackoy (1996), there exist close and strong-tie relationship between banking services quality, satisfaction, and customer loyalty. To this end, this study is an attempt to design a regression model and develop a SEM for earning loyalty of Tejarat Bank customers.

\section{The Literature Review}

Benefits of creating and maintaining the quality of services along with the desired and high quality of services are considered to be powerful tools in approaching competitive advantages of business and organizations. In fact, high quality of products and services might entail customer satisfaction. Services quality has impact on customer satisfaction and it possesses advantages. It includes creating harmony between business and customer, foundation of bases for further purchase, encouraging customer loyalty, giving order through verbal expressions, determining popularity in the minds of customers, and increasing the benefits of business (Rizan, 2010).

The concept of services quality, satisfaction, and loyalty are related to one another. The quality of service affects customer loyalty both directly and indirectly through customer satisfaction. If the performance of a product or service is lower than expectations, customers will be dissatisfied. This dissatisfaction will lead to customer avoidance from long-term commitment and they will go after other competitors. This consideration implies that this will lead to less benefit and decrease in selling (Cronin \& Taylor, 1992).

Helgesen and Nesset (2007) argue that supporting the services quality ends up in customer satisfaction and then the process of loyalty becomes available. Cöner and Güngör (2002) studied the customer loyalty in accordance with the quality of product and services and customers' perception about them. They mentioned that the quality of product and services is in direct relationship with customer satisfaction which leads to their loyalty. In addition, 
services quality and its improvement are preliminary steps to customer satisfaction and customer loyalty is a valuable outcome of satisfaction (Cornin \& Taylor, 1992).

Spreng and Mackoy (1996) investigated the high correlation between elements of customer satisfaction and services quality. Their observations provided compelling evidence that in some occasions there exist gaps between customer satisfaction and services quality. However, wide ranges of research in causal order of conceptual model imply the relationship between these two variables and evaluate their association (Dado, Petrovicova, Cuzovic, \& Rajic, 2012).

Turban, King, Lee, and Viehland (2006) approved the correlation between services quality and relationship with customer in relation with loyalty and they emphasized that the existence of high quality of services and having appropriate relationship with customers lead to customer retention in relation with their loyalty for profitability of a business. The quality of relationship with customers depends on customers' high reliability to service providers. Therefore, this causes continuous and long-term commitment. Consistent with this notion, it can be stated that reliability tends to be important for both sides. Besides, one of businesses' true purposes is spending much time and effort to improve the services quality of their business with the primary objective of providing customer satisfaction and loyalty for longterm commitment. It is worth noting that the quality of relationship with customers along with effect on customer satisfaction can influence customer loyalty both indirectly and directly (Anderson, Jain, \& Chintagunta, 1993; Buttle, 2004; Turban, King, Lee, \& Viehland, 2006).

The findings of studies conducted by Rahmani and Varedi (2013), Heng, et al. (2011), Lenka, Suar, and Mohapatra (2009), and Luaran and Lin (2004) who attempted to investigate the impact of relationship quality with customers, direct effect of services quality and its indirect effect on loyalty through satisfaction, role and importance of services quality on customer satisfaction, and the customer loyalty to bank, respectively, revealed that services quality and customer satisfaction had direct and indirect effect on customer loyalty. Also, investigation of Ou, Shih, Chen, and Wang (2011) revealed the meaningful effect of services quality on customer loyalty. The role and impact of services quality on customer satisfaction was confirmed in a research by Yang and Peterson (2004). Moreover, Onditi, Oginada, Ochieng, and Oso (2012) approved the implications of services quality on customer loyalty in the banking sector in Kenya. Koçoğlu and Kirmaci (2012) highlighted the prominent influence of Keshavarzi Bank's way of establishing relationship with customers in Turkey 
and he stated that customer satisfaction led to customer loyalty. The findings of Shanka (2012) in an Ethiopian banking sector revealed the close relationship of banking services quality and customer satisfaction and loyalty with bank. Tee, et al. (2012) emphasized the determinant role of customer satisfaction of banking services and its positive effects on customer loyalty. The summary of supporting backgrounds of relationships between research variables are represented in Table 1.

Table 1

Summary of Supporting Backgrounds of Relationships between Research Variables

\begin{tabular}{ll}
\hline \multicolumn{1}{c}{ Research Variables and the Relationship between them } & \multicolumn{1}{c}{ Researchers } \\
\hline Quality of relationship with customer and loyalty & $\begin{array}{l}\text { Rahimnia, Harandi, \& Fatemi (2013); Sheth, Parvatiyar, \& Shainesh } \\
\text { (2007); Wong \& Sohal (2002) } \\
\text { Onditi, Oginada, Ochieng, \& Oso (2012); Ou, Shih, Chen, \& Wang } \\
\text { (2011) }\end{array}$ \\
$\begin{array}{ll}\text { Relationship between services quality and loyalty } \\
\text { Relationship between services quality and satisfaction }\end{array}$ & $\begin{array}{l}\text { Tee, et al. (2012) } \\
\text { Relationship between satisfaction and customer loyalty }\end{array}$ \\
$\begin{array}{l}\text { Relationships between services quality, relationship quality with \& Fatemi (2013) } \\
\text { customers, and loyalty }\end{array}$ & $\begin{array}{l}\text { Helgesen \& Nesset (2007); Lenka, Suar, \& Mohapatra (2009); Luaran } \\
\text { Relationships between services quality, satisfaction, and loyalty }\end{array}$ \\
$\begin{array}{l}\text { \& Lin (2004); Shanka (2012) } \\
\text { satisfaction, and loyalty }\end{array}$ & $\begin{array}{l}\text { Dado, Petrovicova, Cuzovic, \& Rajic (2012); Koçoğlu \& Kirmaci } \\
\text { (2012) }\end{array}$ \\
\hline
\end{tabular}

\section{Research Hypotheses}

Based on the studies conducted to date and the perceived gap in this field of study, the following research hypotheses were formulated:

$\mathbf{H}_{1}$ : Banking services quality has a positive effect on customer loyalty of Tejarat Bank in Ardabil.

$\mathbf{H}_{2}$ : Quality of bank relationship with customer has a positive effect on customer loyalty of Tejarat Bank in Ardabil.

$\mathbf{H}_{3}$ : Satisfaction from banking services quality has a positive effect on customer loyalty of Tejarat Bank in Ardabil.

$\mathbf{H}_{4}$ : Banking services quality has a positive effect on quality of Tejarat Bank relationship with customers in Ardabil.

$\mathbf{H}_{5}$ : Banking services quality has a positive effect on customer satisfaction from Tejarat Bank in Ardabil.

$\mathbf{H}_{6}$ : Quality of bank relationship with customer has a positive effect on customer satisfaction of Tejarat Bank in Ardabil.

\section{Method}


The purpose of this research was designing a regression model and developing a structural equation modeling (SEM) for earning loyalty of Tejarat Bank customers. The current study was an objective research and it was carried out through a survey method using questionnaire as the main instrument. In order to avoid population skewness, and also because of giving equal chances for population for being selected, probability sampling method was applied. Regarding the importance of samples in creation process of SEM, the sample size of present research using the Cochran's formula considered to be 384 people. To increase the level of confidence, 400 questionnaires distributed among regular customers of Tejarat Bank branches. The main research instrument was a researcher-made questionnaire and it included 28 questions. The measuring scale of items was 5-point Likert scales that ranged from "so much" to "very low". The hypotheses were tested using the SPSS and LISREL software.

For evaluating the position of the questionnaire, validity and reliability tests were used. To confirm the validity and reliability of the questionnaire, the researcher asked the ideas of some professors and professional experts of Tejarat Bank branches in Ardabil. Their corrective views applied and it was validated through experts' opinions.

\section{Results}

\section{Exogenous Measurement Model of Research}

Figure 1 shows the results of first-order factor analysis related to services quality. Measurement model of perceived services quality was reasonable and all numbers and indicators were meaningful. 


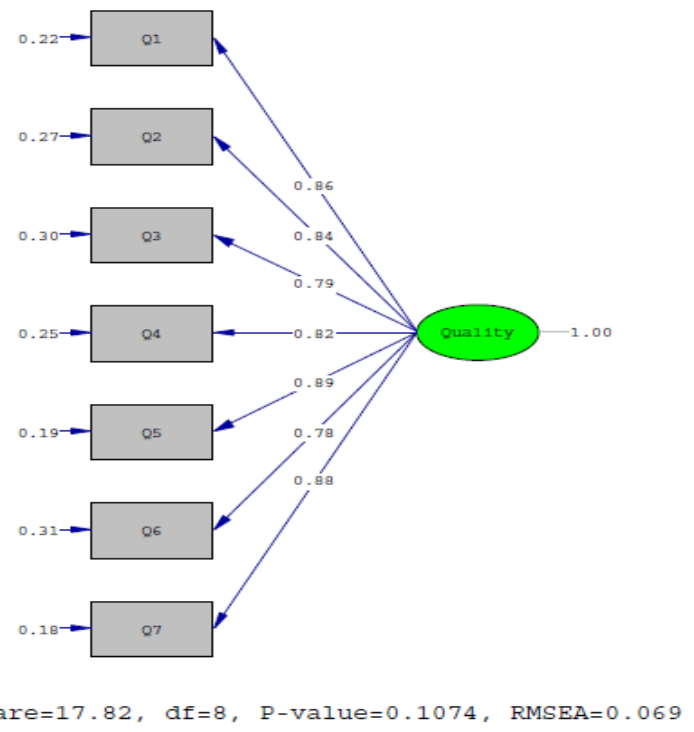

Figure 1. Standard estimation graph of exogenous variable

\section{Endogenous Measurement Model of Research}

The results of first-order confirmatory factor analysis (CFA) of endogenous variables showed that the measurement models of endogenous variables were appropriate and all numbers and indicators of model were favorable. Figure 2 illustrates the standard estimation of endogenous variable.

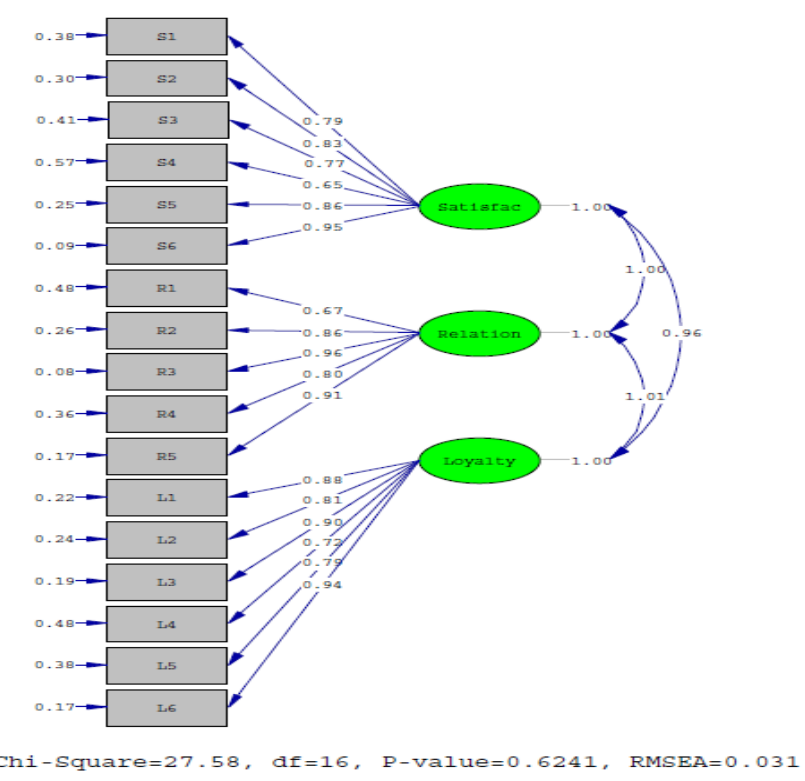

Figure 2. Standard estimation graph of endogenous variable 
To determine the reliability of the questionnaire, internal consistency reliability which is assessed by Cranach's alpha, came into use. Results of reliability analysis revealed that the reliability of all indicators was high and also all were one-dimensional. Put simply, the level of assessed reliability comprised a great level of questionnaire reliability relating to each research variables (above 85 per cent) which indicated the appropriateness of research questions.

Table 2

Reliability Coefficients of Research Variables

\begin{tabular}{lcc}
\multicolumn{1}{c}{ Research Variables } & Number of Questions & Alpha Coefficient $(\alpha)$ \\
\hline Banking Services Quality & 7 & $91 \%$ \\
Quality of Bank Relationship with Customer & 5 & $86 \%$ \\
Customer Satisfaction & 6 & $85 \%$ \\
Customer Loyalty & 6 & $88 \%$ \\
Total & 24 & $93 \%$ \\
\hline
\end{tabular}

\section{Model of Research}

The conceptual model of research was designed according to the SEM. Figure 3 shows the conceptual model of research regarding SEM approach. In this model, services quality was considered as external variable and the other latent variables, including quality of relationship with customers, satisfaction, and customer loyalty were appeared as endogenous variables of research in order to provide the possibility of indirect and direct coefficients assessments.

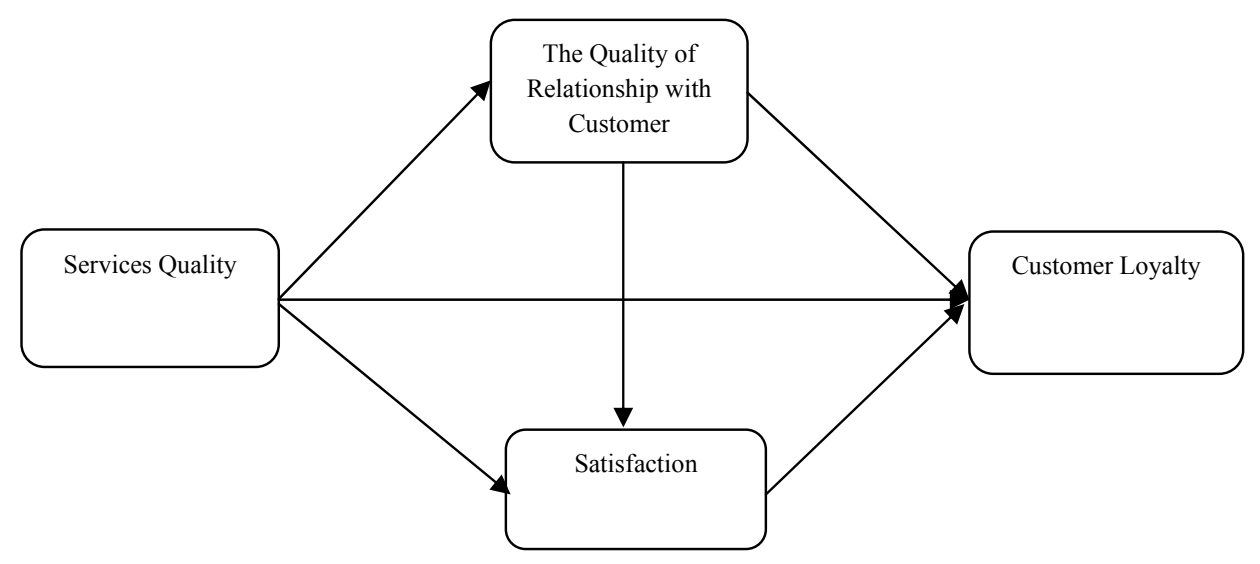

Figure 3. Conceptual model of research

As it is represented in Table 3, the results of descriptive statistics clearly indicated the position and value of measuring scales at two levels of average and less than average. The highest mean percentage was 25 per cent and it referred to banking services quality. The lowest mean percentage was 17.5 per cent and it belonged to quality of bank relationship with customer. Considering the coefficient of variation $(\mathrm{CV})$, it is important to mention that the 
variability level of all variables was above 25 per cent. The high level of CV demonstrated high variability level among calculated samples.

Table 3

Descriptive Statistics of Main Research Variables

\begin{tabular}{|c|c|c|c|c|c|}
\hline Research Variables & Mean & Minimum & Maximum & $\mathrm{SD}$ & $\begin{array}{c}\text { Coefficient of } \\
\text { Variation }\end{array}$ \\
\hline Banking Services Quality & 24.6 & 15 & 34 & 6.2 & $25 \%$ \\
\hline Quality of Bank Relationship with Customer & 17.5 & 11 & 25 & 5.4 & $31 \%$ \\
\hline Customer Satisfaction & 21.8 & 13 & 30 & 6.1 & $28 \%$ \\
\hline Customer Loyalty & 21.7 & 15 & 30 & 6.6 & $30 \%$ \\
\hline
\end{tabular}

The significance level of the linear relationship between the research variables revealed that there was a linear relationship and bivariate correlation between the indicators. The correlation between variables was direct (positive) and the intensity of these correlations was above 66 per cent.

Table 4

Correlation Matrix of Relationships between Research Variables

\begin{tabular}{lcccc}
\hline \multicolumn{1}{c}{ Research Variables } & $\begin{array}{c}\text { Banking Services } \\
\text { Quality }\end{array}$ & $\begin{array}{c}\text { Quality of Bank } \\
\text { Relationship with Customer }\end{array}$ & $\begin{array}{c}\text { Customer } \\
\text { Satisfaction }\end{array}$ & $\begin{array}{c}\text { Customer } \\
\text { Loyalty }\end{array}$ \\
\hline Banking Services Quality & 1 & & & \\
Quality of Bank & $69 \%^{* *}$ & 1 & & \\
Relationship with Customer & & & 1 & 1 \\
Customer Satisfaction & $66 \%^{* *}$ & $88 \%^{* *}$ & $80 \%^{* * *}$ & 1 \\
Customer Loyalty & $91 \%^{* *}$ & $85 \%^{* *}$ & &
\end{tabular}

** Significant at $1 \%$ level

Table 5 shows the results of research hypothesis using Pearson's correlation coefficient.

Table 5

Results of Research Hypotheses Using Pearson's Correlation Coefficient

\begin{tabular}{|c|c|c|c|c|}
\hline Hypotheses & Research Variables & Coefficient & Sig & Result \\
\hline $\mathrm{H}_{1}$ & $\begin{array}{l}\text { Banking services quality has a positive effect on customer } \\
\text { loyalty of Tejarat Bank in Ardabil. }\end{array}$ & $91 \%$ & Less than $5 \%$ & Approved \\
\hline $\mathrm{H}_{2}$ & $\begin{array}{l}\text { Quality of bank relationship with customer has a positive } \\
\text { effect on customer loyalty of Tejarat Bank in Ardabil. }\end{array}$ & $85 \%$ & Less than $5 \%$ & Approved \\
\hline $\mathrm{H}_{3}$ & $\begin{array}{l}\text { Satisfaction from banking services quality has a positive } \\
\text { effect on customer loyalty of Tejarat Bank in Ardabil. }\end{array}$ & $80 \%$ & Less than $5 \%$ & Approved \\
\hline $\mathrm{H}_{4}$ & $\begin{array}{l}\text { Banking services quality has a positive effect on quality of } \\
\text { Tejarat Bank relationship with customers in Ardabil. }\end{array}$ & $69 \%$ & Less than $5 \%$ & Approved \\
\hline $\mathrm{H}_{5}$ & $\begin{array}{l}\text { Banking services quality has a positive effect on customer } \\
\text { satisfaction from Tejarat Bank in Ardabil. }\end{array}$ & $66 \%$ & Less than $5 \%$ & Approved \\
\hline $\mathrm{H}_{6}$ & $\begin{array}{l}\text { Quality of bank relationship with customer has a positive } \\
\text { effect on customer satisfaction of Tejarat Bank in Ardabil. }\end{array}$ & $88 \%$ & Less than $5 \%$ & Approved \\
\hline
\end{tabular}

\section{Regression Modeling}

Considering the amount of multivariate correlation, the results of regression modeling ( 86 per cent) was obtained using LISREL. It indicated that there was a close and strong relationship between the independent variables of regression model with customer loyalty. Besides, the regression model has strict conformity with data and it possesses more suitability. 
Also, the existing coefficient determination of model showed that a series of dependant variables relating to banking services quality, quality of bank relationship with customer, and customer satisfaction determined the 75 per cent of total variability of customer loyalty and the other varieties were due to other factors that were unknown to the researcher.

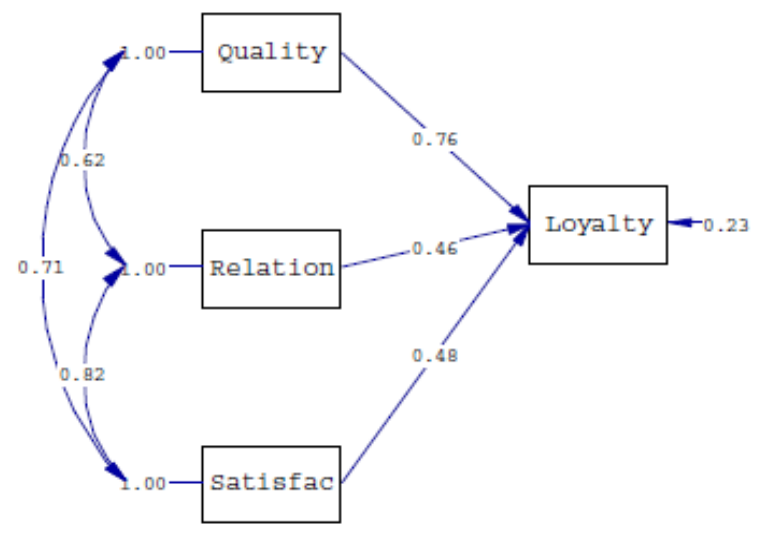

Figure 4. Standard regression model of customer satisfaction

Services quality with 76 per cent of coefficient possessed precise level of prediction and it indicated the importance of banking services quality in the process of inspiring and earning customer loyalty in comparison with customer satisfaction with 48 per cent of regression coefficient and quality of bank relationship with customers comprising 46 per cent of regression coefficient.

Table 6

Regression Analysis of Customer Loyalty

\begin{tabular}{lccc}
\hline \multicolumn{1}{c}{ Independent Variables } & B & Standardized Coefficients & T-Value \\
\cline { 2 - 4 } & $69 \%$ & Beta & T \\
\hline Quality of Banking Services & $41 \%$ & $76 \%$ & 2.13 \\
Quality of Bank Relationship & & $46 \%$ & 3.97 \\
with Customer & $43 \%$ & $48 \%$ & \\
Customer Satisfaction & $\quad$ & $75 \%$ & \\
\hline \multicolumn{2}{c}{ Coefficient of Determination (R) } \\
$\quad$ Multiple correlation coefficient (R) & $86 \%$ & \\
\hline
\end{tabular}

The results of SEM according to standard estimation demonstrated that the direct effect of banking services quality on customer loyalty was 73 per cent. Moreover, its effect on quality of bank relationship with customers and satisfaction was 31 per cent for both. The direct effect of quality of bank relationship with customers on customer loyalty and customer satisfaction were 42 per cent and 98 per cent, respectively. In addition, the direct effect of satisfaction on customer loyalty was 43 per cent. The total indirect effect of banking services 
quality on customer loyalty was 31 per cent and its effect on satisfaction was 11 per cent. Also, the total indirect effect of quality of bank relationship with customer on loyalty was considered to be 42 per cent. Figure 5 displays structural model for earning the loyalty of Tejarat Bank customers.

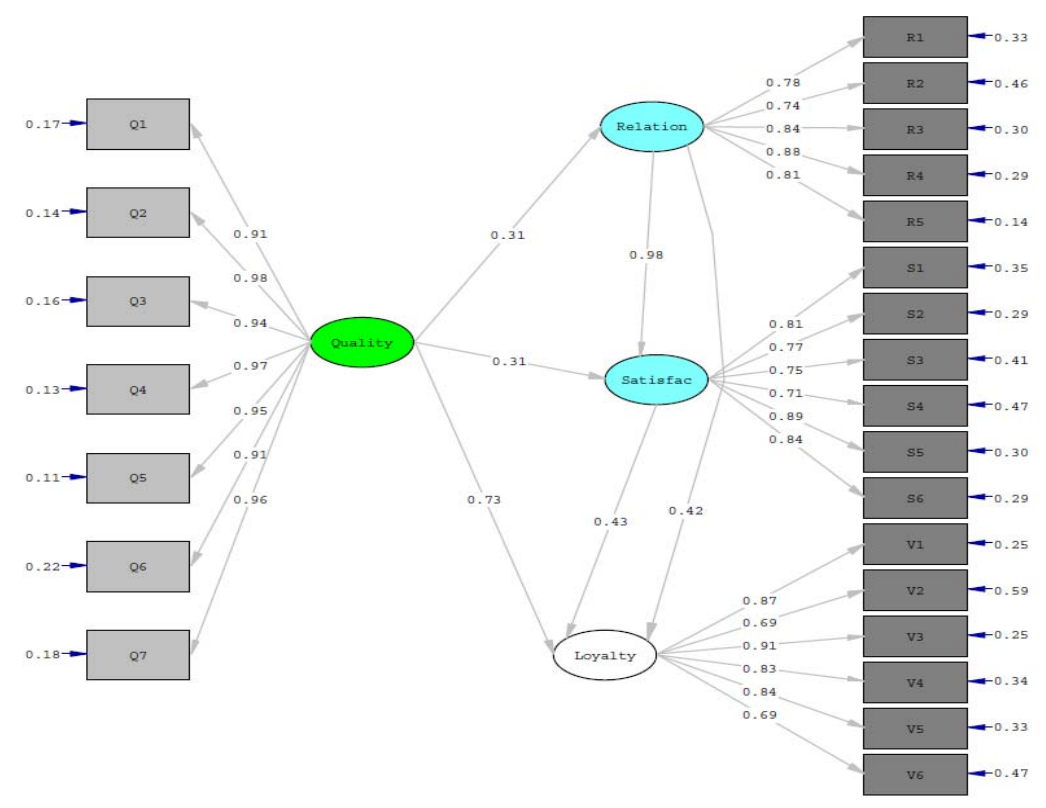

Figure 5. Structural model for earning the loyalty of Tejarat Bank customers

Goodness-of-fit test of measuring model in relation with observable data indicated a good fit of observed variables. This consideration implied that all observed variables with high level of impact loading (60 per cent) on variables showed suitable fit of measuring model. The root mean square error of approximation (RMSEA) which is known as residual model was equal to 32 per cent and it was less than 0.1 , and it demonstrated great fit of LISREL model. According to the evaluation, the value of goodness-of-fit index (GFI) appeared to be 89 per cent, and it was approximately close to measured scales. The index value of root mean residual (RMR) was estimated to be 0.026 that was indicative of good fit of model.

Finally, as it can be seen from Table 7, goodness-of-fit tests of theoretical framework along with the observed data were representative of relatively high fit of model. Suitable fit of structural model with reference to value of chi-square degree of freedom (CMIN) was between 1 and 3 which indicated suitable fit of model. 
Table 7

Goodness-of-Fit Indicators of LISREL Model for Earning Customer Loyalty

\begin{tabular}{ccccc}
\hline Abbreviation & $\mathrm{X}^{2}$ & CMIN/df & GFI & RMR \\
\hline Name of Indicators & $\begin{array}{c}\text { Level Covered by } \\
\text { Chi-Square }\end{array}$ & $\begin{array}{c}\text { Chi-Square Degree } \\
\text { of Freedom }\end{array}$ & $\begin{array}{c}\text { Goodness-of-Fit } \\
\text { Indicator }\end{array}$ & $\begin{array}{c}\text { Root Mean Residual } \\
\text { Root Mean Square } \\
\text { Error of } \\
\text { Approximation }\end{array}$ \\
Coefficients & 0.612 & 1.66 & 0.89 & 0.041 \\
Acceptable Fit & $.05 \mathrm{X}^{2}>$ & $\begin{array}{c}\text { Quantity between 1 } \\
\text { and 3 }\end{array}$ & Near to Zero & $10 \%$ RMSEA \\
\hline
\end{tabular}

\section{Discussion and Conclusion}

The study was therefore an attempt to design a regression model and to develop a SEM for earning loyalty of Tejarat Bank customers. Based on the findings of this, one can come to conclusion that there was a meaningful relationship between variables of research. Also, this relationship confirmed the theoretical frameworks and experimental backgrounds used in this research. The findings showed that customer loyalty in the first place depends on banking services quality. This means that more effort is needed in banking services quality management and in its promotion; because services quality tends to be significant determinant of customer loyalty. Following this, banks have to establish long-term relationships with customers. It is significant that they should make one-to-one and individualized relationships with their customers and determine their needs. Besides, banks should focus on customers' tastes and their behavioral habits toward banking services environment, and arouse in them the sense that they are valued by fulfilling their expectations to gain loyal customers. Customers directly gain loyalty from the process of services quality. Considering this fact, when they perceive higher services quality, they turn a loyal customer to the bank.

Attracting loyal customers implies having profound knowledge about customers and publishing brochures on the basis of improving the level of services quality. The improvement of services quality depends on different ways of informing at bank branches. Customers' high level of satisfaction is also of great importance. Banks should note all the factors that are found to cause satisfaction and loyalty. Improving the level of services quality leads to improvement of customer satisfaction. Put simply, Tejarat Bank can create satisfaction from responding to customers, providing requirements of banking loan and banking facilities, eliminating discrimination between customers, and focusing on concepts of customer orientation. Banks can do these by facilitation and simplification of banking 
services quality and by having certain ways of communicating with customers in order to build trust and meet commitments in relationships.

Designed structural model of this research considers improving the level of banking services quality as a base for gaining customer loyalty. Exerting direct effect on customer loyalty, improving the quality of bank relationship with customers, and also enhancing their satisfaction will enable Tejarat Bank to retain their existing customers and gain customer loyalty in branches of Ardabil. In summary, customer retention influences the success of the banks. It is desirable that this research be extended to a wider scale, where more respondents from different banks are included in the study and would allow for more generalizations to be made.

\section{References}

Anderson, J. C., Jain, D. C., \& Chintagunta, P. K. (1993). Customer value assessment in business markets: A state of practice study. Journal of Business-to-Business Marketing, 1(1), 3-29.

Buttle, F. (2004). Customer relationship management: Concepts and tools. London: Elsevier.

Cöner, A., \& Güngör, M. O. (2002). Factors affecting customer loyalty in the competitive Turkish metropolitan retail markets. Journal of American Academy of Business, 2(1), 189-195.

Cronin, J. J. Jr., \& Taylor, S. A. (1992). Measuring service quality: A reexamination and extension. Journal of Marketing, 56(3), 55-68.

Dado, J., Petrovicova, J. T., Cuzovic, S., \& Rajic, T. (2012). An empirical examination of the relationships between service quality, satisfaction and behavioral intentions in higher education setting. Serbian Journal of Management, 7(2), $203-218$.

Gustafsson, A., Johnson, M. D., \& Roos, I. (2005). The Effects of customer satisfaction, relationship commitment dimensions, and triggers on customer retention. Journal of Marketing, 69, 210-218.

Helgesen, Ø., \& Nesset, E. (2007). What accounts for students' loyalty? Some field study evidence. International Journal of Educational Management, 21(2), 126-143.

Heng, K. C., Yeong, K. S., Siong, L. C., Shi, T. Y., \& Kuan, Y. M. (2011). Customers' perceptions of the marketing mix and the effect on Malaysian Hypermarkets' brand loyalty (Honours dissertation). Universiti Tunku Abdul Rahman, Turkey.

Kaur, M., Sharma, N., \& Kapoor, S. (2012). Customer satisfaction in banking industry: A gap analysis approach. Asia Pacific Journal of Management Research \& Innovation, 8(4), 399-406.

Koçoğlu, D., \& Kirmaci, S. (2012). Customer relationship management and customer loyalty: A survey in the sector of banking. International Journal of Business \& Social Science, 3(3), 282-291.

Kotler, P., \& Armstrong, G. (2012). Principles of Marketing(14 ${ }^{\text {th }}$ ed.). USA, New Jersey: Pearson Education Inc.

Lenka, U., Suar, D., \& Mohapatra, K. J. P. (2009). Service quality, customer satisfaction, and customer loyalty in Indian commercial banks. Journal of Entrepreneurship, 18(1),47-64.

Luarn, P., \& Lin, H. H. (2004). A customer loyalty model for e-service context. Journal of Electronic Commerce Research, $4(4), 156-167$.

Oliver, R. L. (1999).Whence consumer loyalty? Journal of Marketing, 63(1), 33-44.

Onditi, A. A., Oginada, M. N., Ochieng, I., \& Oso, W. (2012). Implications of service quality on customer loyalty in the banking sector: A survey of banks in Homabay county, Kenya. International Journal of Business \& Social Science, 3(21), $223-233$.

Ou, W. M., Shih, C. M., Chen, C. Y., \& Wang, K. C. (2011). Relationships among customer loyalty programs, service quality, relationship quality and loyalty: An empirical study. Chinese Management Studies, 5(2), 194-206.

Rahimnia, F., Harandi, A., \& Fatemi, Z. (2013). Impact of the quality of relationship with the customer on perceived quality and customer loyalty: A case study of five-star hotels in Mashhad. Journal of Management, 5(17), 83-101. 
Rahmani, z., \& Varedi, F. (2013). Attraction and retention of customers in the development and success of the banks. Paper presented at the National Conference of Entrepreneurship and Knowledge Based Business Management, Mazandaran, Iran.

Rizan, M. (2010). Analysis of service quality and customer satisfaction and its influence on customer loyalty. Paper presented at the Oxford Business \& Economics Conference Program, Oxford University, Oxford, UK.

Salarzehi, H., \& Amiri, Y. (2012). Factors affecting the process of customer relationship management in insurance companies. Journal of Management, 4(12), 131-144.

Shanka, M. S. (2012). Bank service quality, customer satisfaction and loyalty in Ethiopian banking sector. Journal of Business Administration \& Management Sciences Research, 1(1), 1-9.

Sheth, J. N., Parvatiyar, A., \& Shainesh, G. (2007). Customer relationship management. New Dehli: Tata McGraw-Hill.

Singh, S., \& Rahul, M. (2010). Effectiveness of CRM in banking services with reference to ATM services in NCR Delhi. Asia Pacific Business Review, 6(2),141-149.

Spreng, R. A., \& Mackoy, R. D. (1996). An empirical examination of a model of perceived service quality and satisfaction. Journal of Retailing, 72(2), 201-214.

Tahvildari, M. (2008). Analysis of the factors affecting the customer attraction in Saderat Bank of Iran. Journal of Bank \& Economics, 90, 44-48.

Tee, C. H., Thoo, A. C., Rasli, A., Md Yussof, R., \& Huam, H. T. (2012). The effects of service quality, customer satisfaction on re-patronage intentions of hotel existing customers. International Journal of Management \& Administrative Science, 1(8), 1-6.

Turban, E., King, D., Lee, J. K., \& Viehland, D. (2006). Electronic commerce: A managerial perspective (4 ${ }^{\text {th }}$ ed.). New Jersey: Prentice Hall.

Wong, A., \& Sohal, A. (2002). Customers' perspectives on service quality and relationship quality in retail encounters. Managing Service Quality, 12(6), 424-433.

Yang, Z., \& Peterson, R. T. (2004). Customer perceived value, satisfaction, and loyalty: The role of switching costs. Psychology \& Marketing, 21(10), 799-822. 